\title{
Three Models for Understanding Gifted Education
}

\author{
Angela Page \\ e-Teacher, The Correspondence School
}

\begin{abstract}
The Ministry of Education (2000) handbook, Gifted and talented students: Meeting their needs in New Zealand Schools requires each school to show they are identifying and catering for their gifted and talented students. The terms 'gifted' and 'talented' represent a range of diverse special abilities rather than describe a single homogenous group or category. Three theories or models of giftedness and talent development are presented in this article, namely Renzulli's (1986) Three ring conception of giftedness, Gardner's (1986) Theory of multiple intelligences, and Gagné's (1992) Differentiated model of giftedness and talent. Each defines and categorises giftedness and talent according to their own criteria. Schools are recommended to have a sound understanding of theories and principles underpinning gifted and talented education, such as those presented in this article, in order to meet the Ministry of Education's requirements and to successfully meet the needs of students who are identified as gifted and talented.
\end{abstract}

\section{Research Paper \\ Keywords}

Cognitive ability, cultural differences, gifted, inclusive education, intelligence, student achievement.

\section{INTRODUCTION}

Gifted and talented education has come to the forefront of New Zealand education in recent years since the release of the Ministry of Education handbook, Gifted and talented students: Meeting their needs in New Zealand schools (2000), and Initiatives for gifted and talented learners (Ministry of Education, 2002). The handbook provides guidelines for meeting the needs of gifted and talented students and is supported by a change to the national administration guidelines (Ministry of Education, 2005) which require all schools to be able to actively demonstrate how they are catering for these needs from Term 1, 2005.

The Ministry of Education handbook (2000) suggests a range of definitions and strategies relevant to gifted and talented education, but clearly states that "each school must develop a set of characteristics that reflects its own definitions of, and approach to, the concept of giftedness and talent" (p. 17). Developing these concepts and strategies can be a difficult and somewhat daunting task for schools to undertake in isolation. While each school is best able to incorporate ideas and strategies relevant to their own unique culture and community, the process of identifying, analysing and adopting these concepts will ultimately require a significant investment of time and effort. In order to successfully meet the needs of gifted and talented students, it is imperative for teachers to gain a sound understanding of the theories and principles underpinning gifted education.

This article will review research relevant to the education of gifted and talented students. It will review a range of literature with the intention of seeking to clarify some of the terminology encountered and concepts underpinning gifted and talented education. It will then present an overview of the characteristics of gifted and talented students, as defined by different researchers. Following this, a critical analysis of the concepts from three theoretical models underpinning gifted and talented education will be made. To conclude, implications and considerations for catering for needs of gifted and talented students in New Zealand schools will be discussed.

Documents such as the Marland report (1972) and the more recent Ministry of Education commissioned research (Riley, Bevan-Brown, Bicknell, Carroll-Lind, \& Kearney, 2004), refer to giftedness as encompassing a wide range of abilities, found across domains such as specific academic, creative, cultural, psychomotor, social, and so forth. The three theories of giftedness and talent development to be examined include a concept of giftedness and talent (Renzulli, 1986), a theory of intelligence (Gardner, 1983) and a conceptualisation of the talent development process (Gagné, 1992). These theories have been selected for examination due to the Ministry of Education (2000) suggesting they be adopted or adapted in establishing school-based definitions of giftedness and talent. This is supported by research carried out by Riley et al. (2004), which reports that these theories are prevalent in New Zealand schools.

\section{TERMINOLOGY}

Many documents, including the Ministry of Education (2000) handbook, use the terms 'gifted' and 'talented' interchangeably, implying a single-concept approach. Frequently, the terms are joined together and referred to as 'gifted and talented', yet others would argue that the terms are not synonymous (see Gagné, 1992). Throughout this paper, the terms 'gifted' and 'talented' will be used in accordance with the models or approaches being discussed. 


\section{CHARACTERISTICS OF GIFTEDNESS}

The Ministry of Education (2000) handbook acknowledges that gifted and talented students are not part of a homogenous group. That is, each individual student presents particular strengths to combine as a unique blend of traits. While a high IQ might have traditionally been a fundamental indicator of giftedness, this is no longer accepted as a sole characteristic, or even sought after by many New Zealand schools. However, it is recognised that there are some common clusters of characteristics pertaining to most gifted students. Highly gifted students may present more marked or intense indicators of these traits.

Generally, identified characteristics of gifted students appear to be positive by nature. That is, indicators mostly show positive facets of a student's aptitude, such as explaining their ability to produce original ideas, be self-directed, pose original ideas and questions, and so forth. However, sometimes extreme examples of characteristics can be viewed less favourably in different social or educational situations. For example, if a gifted student has a strong preference to work alone they may find it difficult to work collaboratively with others.

Cathcart (2005) has adapted a list of characteristics of exceptionally able children as distributed by the US Office of Education. The list includes a wide range of behaviours and abilities, each beginning with the phrase "exceptionally able children often: ..." (p. 17). Many of the skills are comparative with students who are not gifted, for example, gifted students learn basic skills better and with less practice; they are better able to handle abstract ideas; or are better at working independently and sustaining concentration for longer periods.

Moltzen (2004) states that a school's own definition of giftedness will determine the set of characteristics deemed to indicate gifted behaviour. He has compiled lists of characteristics according to six major domains, including general intellectual, creative, leadership, specific academic, visual and performing arts, and psychomotor abilities. The general intellectual abilities list is divided into two domains, reflecting both cognitive and affective characteristics. Gifted students may demonstrate outstanding cognitive or affective abilities, or a combination of the two.

The Ministry of Education (2000), together with the work of Moltzen (2004), suggests that schools use a list compiled by McAlpine and Reid (1996) as a starting point for defining characteristics of gifted children. The document clearly states that "no one gifted student is likely to possess all the following characteristics. It would be possible for a student to show clear evidence of all, or nearly all, the behaviours in one category but few in another" (Ministry of Education, 2000, p. 18). This trend to move away from defining giftedness in terms of a single category acknowledges a more diverse range of special abilities. The five factor scales are:

- learning characteristics

- social leadership characteristics

- creative thinking characteristics

- self-determination characteristics

- motivational characteristics (McAlpine \& Reid, 1996).
The characteristics listed within these factor scales refer to behaviours which may be demonstrated by gifted students, rather than abilities they may possess.

\section{DEFINITIONS AND THEORETICAL MODELS OF GIFTEDNESS}

Various academics and educators have devised their own models and definitions of giftedness and talent. McAlpine (2004) reports of research which has identified 213 definitions of giftedness. Many are based on longitudinal or quantitative studies of gifted children; some have been carried out retrospectively, seeking to identify and compile a list of characteristics demonstrated by high-achieving adults in various fields.

The following sections contain descriptions of three theoretical models of giftedness and talent development. Many characteristics and distinctions overlap between the theories and some appear to be the development of ideas from other sources. It should be remembered that concepts of giftedness and talent are sensitive to time, place and cultural contexts, while being underpinned by social values (McAlpine, 2004).

\section{Renzulli's Three Ring Conception of Giftedness}

Renzulli's (1986) Three ring conception of giftedness has been widely used in schools and educational institutions around the world since its inception. It is based on the interaction between three basic clusters of three human traits, being above average ability, a high level of task commitment, and a high level of creativity. The model was developed from studies examining the traits of highly successful adults in different fields of achievement. Each was shown to possess the above-mentioned traits to various degrees. It should be noted that the degree of manifestation and combinations of these traits are not necessarily equal nor static. While various compositions of these traits can usually be applied to one or two performance areas, there is no 'ideal' combination. 'General' performance areas include mathematics, music, languages, and so on, whereas 'specific' performance areas may include film making, electronics, sculpture, and so on. Ultimately, Renzulli $(1986,1998)$ views giftedness as a behaviour, rather than an attribute.

Renzulli's (1986) conception of giftedness allows students to be identified according to areas not solely relying on formal academic testing. This model has found support amongst teachers whose 'gut instinct' leads them to believe that a particular student is gifted, despite them not necessarily scoring well on formal tests and assessments. Children who appear to be intrinsically motivated and with highly developed special interests and ability in particular areas typify those gifted students encompassed by Renzulli's model. It is also particularly applicable to cultural models of giftedness as it acknowledges the integral and interwoven roles that creativity and task commitment play in addition to above average ability in culturally valued activities.

Where this model falls short is in its ability to identify students who have above average ability and creativity, but are yet to find a context or area of interest in which they excel. That is, their level of task commitment may appear to be lacking, but the reasons for this absence could be that the student 
has not been exposed to the necessary motivations or stimuli to inspire their gifts. Therefore, it is recommended that Renzulli's (1986) model is used in conjunction with other models of giftedness to develop a synthesis of information about a child's ability, with data gathered from a range of sources (Chaffey, 2004). An example of such a model supporting identification could include the Schoolwide Enrichment Model (Renzulli \& Reis, 1994).

\section{Gardner's Theory of Multiple Intelligences}

Gardner's $(1983,1993,1999)$ theory of multiple intelligences moves the focus of identifying giftedness from a single-faceted approach to a multi-category concept. The term 'intelligence' refers to a special ability, talent, or skill which allows a person to maximise their potential by building on the particular strength they demonstrate. The multiple intelligences strongly parallel preferred learning styles or proclivities and, therefore, do not exclusively relate to those who have been identified as gifted and talented.

Armstrong (1987) explains Gardner's multiples intelligences theory by stating that every child possesses aspects of all eight intelligences and can develop them to a fairly high level of competence. By the time a child begins school, they will have established ways of learning which tend to favour some intelligences more than others.

The identification of which intelligences a child has favoured is not a simple process. Anecdotal evidence often comprises much diagnostic and formative assessment for teachers seeking to find out which intelligences their students demonstrate. Close observation of how students choose to spend their free time, or even "misbehave" in class can indicate their preference for learning. For example, a highly linguistic student may frequently choose to read for pleasure, or a spatially-gifted student may draw and 'doodle' while they are thinking (Armstrong, 1987).

Rather than being considered a deficit model for learning, Gardner's (1983) multiple intelligences seek the benefit of working from and developing a child's areas of strength. This philosophy aligns well with principles for gifted and talented education. It is not suggested that students need to master all eight intelligences or focus on gaps in their learning.

As Gardner's (1983) multiple intelligences are applicable, to some degree, to all students, it could be argued that this model is not especially suitable for meeting the needs of gifted students. Le Sueur (2002) strongly states that the unique needs of gifted students must be recognised, valued and catered for. She challenges the teaching strategies and approaches to learning that seem suitable for all students, are not actually meeting the needs of gifted students. If a teacher is using the multiple intelligences as a means for catering for all students in a classroom, then additional approaches and strategies must introduced to truly differentiate the curriculum for those identified as gifted. For example, providing rich learning experiences for all students who demonstrate linguistic intelligence cannot necessarily guarantee assurance for teachers that the needs of their students who are linguistically gifted are being met.
Therefore, it is insufficient to say that the needs of gifted students can be adequately met by using the multiple intelligences model alone. As with Renzulli's (1986) model of giftedness, the multiple intelligences must form a part of an educator's overall understanding about the principles of gifted education and is best used in conjunction with other models.

Gagné's Differentiated Model of Giftedness and Talent Gagné (1992, n.d.) proposes a model which differentiates between giftedness and talent. The differentiated model of giftedness and talent assumes that the terms 'gifted' and 'talented' are not synonymous and cannot be used interchangeably. Analyses of this model, including dialogue by Smith (2004), suggest that it is more a theory of talent development than a definition of giftedness.

Sometimes considered as an extension or development of Renzulli's (1986) Three ring model of giftedness, Gagné (1992) argues that a child's natural abilities in a range of domains constitutes 'giftedness'. 'Talent' is the realisation of a child's giftedness and is enhanced through the intervention of catalysts and other influences. The distinct differentiation between the terms 'giftedness' and 'talent' allows for children who may possess high levels of ability but are yet to use or manifest them to still be identified as gifted. This differentiation addresses a distinct limitation in Renzulli's model, which includes task commitment as a necessary characteristic of giftedness.

Building on a child's natural abilities, a part of the learner's developmental process involves being exposed to a number catalysts. These include the elements in a child's life which can shape the emergence of and the development of their innate abilities. With the intervention of intrapersonal and environmental catalysts, a gifted student may enhance and enrich their natural aptitudes to acquire systematically developed skills, or 'talent'. Therefore, it can be assumed that Gagné (1992) views 'giftedness' as being natural ability or potential, and 'talent' as the product of intervention, or achieving a student's potential through experience.

Gagné's (1992) model formally acknowledges the effect that chance has on natural abilities and catalysts; not all students have sufficient access or the ability to partake in intervention strategies. Also, some gifted children may require lesser degrees or different forms of intervention from intrapersonal and environmental catalysts to be able to fully achieve their potential, or attain 'talented' status. This is a definite strength of the differentiated model, which acknowledges that the presence of developmental processes and catalysts can promote movement between the domains of giftedness and talent.

\section{IMPLICATIONS FOR NEW ZEALAND SCHOOLS}

The Ministry of Education (2000), based on the research of Moltzen, McAlpine and others, acknowledges that each community will have their own unique ideas about what constitutes giftedness and talent. Recognising skills and abilities is contextualised in a particular culture, ethnic group, time, or place. For this reason, all New Zealand schools must form their own definition of giftedness and develop strategies to meet identified needs. 
While it is expected that definitions, approaches and strategies will vary between schools and communities, it is important for teachers to base programmes of learning on a sound understanding of the theories and principles underpinning gifted education. It is recommended that schools gather a range of research and educational theories, determine what is most relevant and appropriate to their particular community, then implement programmes of learning based on this information. All schools should regularly evaluate and review their approaches to gifted education in order to ensure the principles of gifted education are being addressed, and to keep up to date with current best-practice models and other relevant theories and research.

For New Zealand schools, it is particularly important to examine concepts and principles of Māori special abilities. Research carried out by Bevan-Brown (2004) and as discussed by Macfarlane and Moltzen (2005) has found that while there are a multitude of apparent similarities with mainstream education, there are a number of Māori-specific concepts on special abilities which need to be considered. These concepts may be broader and wider-ranging than traditional Western views of giftedness, favouring a more holistic approach and including values and qualities linked with spiritual, cognitive, affective, aesthetic, artistic, psychomotor, social, intuitive, creative, leadership and cultural domains. It is recommended that educators consult with Māori and work in partnership to identify and develop the potential of students with special abilities. Also, close links between home and school are especially critical to ensure success for gifted Māori students.

\section{SUMMARY}

This article has examined literature in the field of gifted and talented education. It has explored and analysed three major theories of giftedness and talent development utilised in New Zealand, that of Renzulli's (1986) Three ring conception of giftedness, Gardner's (1983) Multiple intelligences, and Gagné's (1992) Differentiated model of giftedness and talent. Specific terminology relating to each model was discussed, as well as exploration into the most appropriate use of the terms 'gifted' and 'talented'. Finally, some considerations and implications for catering for gifted and talented students in New Zealand schools were established.

As New Zealand schools work to meet the recommendations set by the Ministry of Education's (2000, 2002, 2005) gifted and talented guidelines, it is important that sound theories and principles underpin any programmes of learning developed by teachers. By exploring and utilising the plethora of quality research available, New Zealand schools have a strong base from which to begin developing their own principles and practices for gifted education. The challenge is for all schools to effectively meet the needs and raise the potential of all their gifted and talented students

\section{REFERENCES}

Armstrong, T. (1987). Multiple Intelligences in the classroom. Alexandria, VA: Association for Supervision and Curriculum Development.

Bevan-Brown, J. (2004). Gifted and talented Māori learners. In D. McAlpine \& R. Moltzen (Eds.), Gifted and talented: New Zealand perspectives (2nd ed., pp. 171-198). Palmerston North, New Zealand: Kanuka Grove Press.
Cathcart, R. (2005). They're not bringing my brain out: Understanding and working with gifted and talented learners (3rd ed.). Auckland: Hodder Education.

Chaffey, G. W. (2004). Low self-efficacy: An important talent mask for 'at risk' gifted children? QAGTC, 24(2), 9-14.

Gagné, F. (1992). On the differentiated nature of giftedness. Keynote address at Guiding the Gifted National Conference: Proceedings of the Guiding the Gifted Conference, Auckland.

Gagné, F. (n.d.). Gifted and Talented Students: A Differentiated Model of Giftedness and Talent. Retrieved May 20, 2006, from http://www.tki.org.nz/r/gifted/reading/theory/ francoys-gagne_e.php

Gardner, H. (1983). Frames of mind: The theory of multiple intelligences. New York: Basic Books.

Gardner, H. (1993). Multiple intelligences: The theory in practice. New York: Basic Books.

Gardner, H. (1999). Intelligence reframed: Multiple intelligences for the 21st Century. New York: Basic Books.

Le Sueur, E. (2002). Making the optimal match: Meeting the needs of gifted students. New Zealand Principal, 17(1), 16-18.

McAlpine, D. (2004). What do we mean by gifted and talented?. In D. McAlpine \& R. Moltzen (Eds.), Gifted and talented: New Zealand perspectives (2nd ed., pp. 33-66). Palmerston North, New Zealand: Kanuka Grove Press.

McAlpine, D., \& Reid, N. (1996). Teacher observation scales for identifying children with special abilities. Wellington: New Zealand Council for Educational Research, and Palmerston North: Massey University ERDC Press.

Macfarlane, A., \& Moltzen, R. (2005). Whiti ki runga! Gifted and talented Māori learners. Kairaranga, 6(2), 7-9.

Marland, S. P. (1972). Education of the gifted and talented. Vol 1. Report to the Congress of the United States Commissioner of Education. Washington, DC: US Government Printing Office.

Ministry of Education (2000). Gifted and talented students: Meeting their needs in New Zealand schools. Wellington, New Zealand: Learning Media.

Ministry of Education (2002). Initiatives for gifted and talented learners. Retrieved May 20, 2006, from http://www.tki.org.nz/r/gifted/initiatives_e.php

Ministry of Education (2005). The National Administration Guidelines. Retrieved May 20, 2006, from http://www.minedu. govt.nz/index.cfm?layout=document\&documentid= $8187 \&$ data $=1$

Moltzen, R. (2004). Characteristics of gifted children. In D. McAlpine \& R. Moltzen (Eds.), Gifted and talented: New Zealand perspectives (2nd ed., pp. 67-92). Palmerston North, New Zealand: Kanuka Grove Press.

Renzulli, J. (1998). The three ring conception of giftedness. In S. Baum, S. Reis \& L. Maxfield (Eds.), Nurturing the gifts and talents of primary grade students. Mansfield Centre, CT: Creative Learning Press. Retrieved May 20, 2006, from http://www.sp.uconn.edu/ nrcgt/sem/semart13. html 
Renzulli, J. (1986). The three ring conception of giftedness: A developmental model for creative productivity. In R. J. Sternberg \& J. E. Davidson (Eds.), Conceptions of Giftedness (pp. 51-92). New York: Cambridge University Press.

Renzulli, J. S., \& Reis, S. M. (1994). Research related to the Schoolwide Enrichment Model. Gifted Child Quarterly, 38, 2-14.

Riley, T., Bevan-Brown, J., Bicknell, B., Carroll-Lind, A., \& Kearney, A. (2004). The extent, nature and effectiveness of planned approaches in New Zealand schools for providing for gifted and talented students. Wellington, New Zealand: Ministry of Education Research Division.

Smith, D. (2004). Gagné's DMGT - There is a difference. Tall Poppies, 29(2), 8-9.

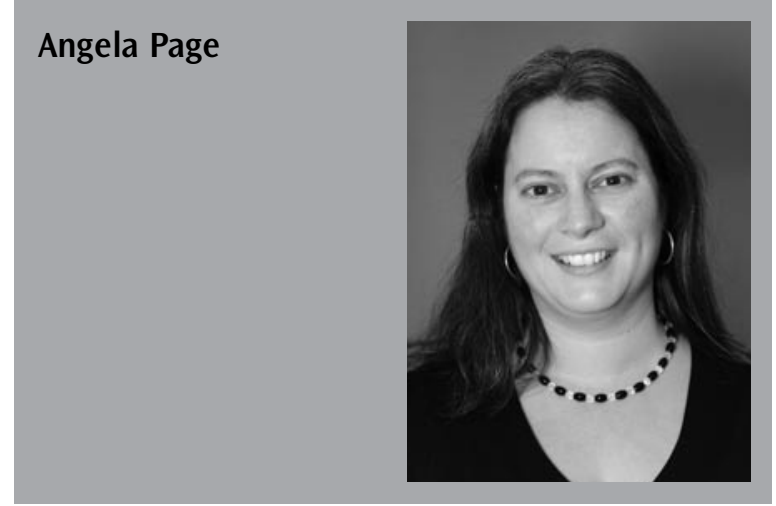

\section{AUTHOR PROFILE}

Angela Page is a primary teacher who specialises in e-learning and teaching gifted and talented students. She has recently completed a Master of Education focusing on the teaching of higher order thinking and is currently an e-teacher at The Correspondence School.

\section{Email}

angela.page@email.com 